\title{
炭化水素酵母の給与におけるビタミン $\mathrm{B}_{12}$ の添加が
}

\section{ブロイラーの発育に及ぼす影響}

\author{
多田昌男1) - 古市比天司1) - 妹尾 文雄 ${ }^{1)}$ - 番匠宏行 ${ }^{2}$ \\ 山中敬三 ${ }^{2)}$ ・岩瀬 伸夫 $^{3)}$ ・八幡策郎 ${ }^{3)}$
}

1）岡山県養鶏試験場

2）広島県立畜産試験場三次支場

3）島根県立畜産試験場

炭化水素酵母（以下，酵母と略す）の給与試験につい ては,すでにいくつかの研究成績が発表されており1 10), アミノ酸2)やビタミン $\mathrm{B}_{12}{ }^{6)}$ などの栄養素に十分配慮し て飼料中に配合するならば，ブロイラー用 $1,2,4,5)$ や産卵 用 $2,3,10)$ の飼料蛋白質源として魚粉や大豆粕とおきかえ 得るとされている。

しかし，魚粉と大豆粕の一部もしくは全部とおきかえ て酵母を卵用鵎に $10 \%$ から $20 \%$ まで給与したところ， 産卵と受精率においては魚粉と大豆粕を主要な蛋白質源 とする対照飼料給与区との間に差がなかったが，ふ化率 が低下した。そこでこの原因を調査した結果，既報6)の ように酵母のビタミン $\mathrm{B}_{12}$ 含量は $1 \mathrm{~g}$ 当たり $0.02 \mu \mathrm{g}$ しかなく，このため酵母飼料中には，ふ化に必要なビタ ミン $\mathrm{B}_{12}$ が不足していたことが認められた。

次に，ブロイラーに対しても卵用䳕と同様に，魚粉と 大豆粕の一部もしくは全部とおきかえて酵母を $10 \%$ か ら $20 \%$ まで給与したところ，酵母の添加量が増加する にしたがって増体量が直線的に低下寸ることが認めら 机，酵母多給に法何らかの問題があることが指摘され た。

そこでこれらの問題を解明するため 3 回の実験を共 同で行なったので報告する。

\section{実験材料および方法}

この研究は, 岡山県養鷄試験場 (以下岡山), 㕕島県 立畜産試験場三次支場（以下広島）および島根県立畜産 試験場（以下島根）の共同研究として, 実験 I は岡山単 独で, 実験 II は岡山, 広島の 2 県で, 実験III岡山, 広 島，島根の 3 県でそれぞれ実施した。

供試ヒナおよび飼育法：実験 Iでは 1969 年 10 月飭付 けの市販ブロイラー専用種（WC $\times W R$ 大型）雌雄 各 200 羽ずつを, 雌雄 別飼いでそれぞれ 50 羽ずつの 4 区 に区分した。実験 IIでは 1970 年 10 月餌付けのブロイラ 一専用種（WC $\times$ WR, 岡山は市販大型, 広島は自場産 昭和 48 年 1 月 19 日受付
兵庫種畜牧場系中型）を各場ごとに雌雄各 225 羽ずつ， 此雄別飼いでそれぞれ 25 羽ずつの 9 区に区分した。実 験IIIでは 1971 年 10 月慨付けのブロイラー専用種（WC $\times \mathrm{WR}$ ，岡山と広島は実験 II と同系統，島根は市販大 型）を各場ごとに雌雄各 225 羽ずつ，雌雄別飼いでそれ ぞれ 25 羽ずつの 9 区に区分した。

供試ヒナの飼育は各場慣行の方法で餌付けから 10 週 齢まで立体で管理した。ヒナの䂆媁生については各場 慣行の衛生プログラムによりそれぞれ行なった。慨付時 に打ける 1 羽平均体重は場によって雌雄別または雌雄平 均で測定したが， 4,8 および 10 週歯における 1 羽平均 体重は, 各区の個体測定值から求めた。

飼料摂取量は 2 週ごとに各区を雌雄の群別に測定し, $0 \sim 4,4 \sim 8,8 \sim 10$ 週齢に区分して集計し, 飼料要求率 は飼料掑取量の週歯区分にしたがって, 飼料摂取量と増 体量との対比から求めた。なお, 育成率は慨付羽数に対 与る 10 週歯令の残存羽数比から求めた。

試験飼料の組成：各実験とも試験飼料はすべて，黄色 とうもるこし, 大豆粕, ふすま, 大豆油, アルファルフ アーミール，魚粉を主体とするもので，実験 I では魚粉 の全量と大豆粕の一部もしくは全部，実験 II では魚粉の 全量もしくは一部と大豆粕の一部, 実験III゙は魚粉の全 量々大豆粕の一部を，それぞれ酵母とおきかえた。慨付 けから 4 週齢までは前期用を, 4 週龄から 10 週歯令までは 後期用飼料をそれぞれ給与したが，飼料の配合は各場ご とに行なった。

試験飼料の粗蛋白質含量 (CP) は前期用が実験 I では $20 \%$ ，実験 II，IIIでは $22 \%$ ，後期用が実験 I では $18 \%$ ， 実験 II，III では $20 \%$ になるように，また，可消化養分 総量 (TDN) は各実験とも前期用が $68 \%$, 後期用が $73 \%$ になるように各区を一定にし，しかも，なるべく単純な 組成となるように設計した。

酵母の配合は実験 I では 10, 15 および $20 \%$ ，実験 II， III では各区ともそれぞれ 15\%にはるようにした。その 場合, 酵母の CP 洛実験とも $59 \%$, TDN は実験 I で 
表 1 . 飼 料 組 成 (後期用)

Table 1. Composition of diet (Broiler finisher)

\begin{tabular}{|c|c|c|c|c|c|c|c|c|c|c|c|}
\hline $\begin{array}{l}\text { 試 験 区 } \\
\text { Treatment }\end{array}$ & $\begin{array}{l}\text { 黄色とう } \\
\text { 方こし } \\
\text { Yellow } \\
\text { corn }\end{array}$ & $\begin{array}{c}\text { 大豆粕 } \\
\text { Soybean } \\
\text { meal }\end{array}$ & $\begin{array}{l}\text { ふすす } \\
\text { Wheat } \\
\text { bran }\end{array}$ & $\begin{array}{c}\text { 大豆油 } \\
\begin{array}{c}\text { Soybean } \\
\text { oil }\end{array}\end{array}$ & $\begin{array}{c}\text { 魚 粉 } \\
\text { Fish } \\
\text { meal }\end{array}$ & 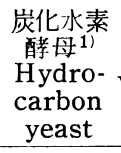 & $\begin{array}{c}\text { ビタミン } \\
\left.\mathrm{B}_{12^{2}}\right)^{-} \\
\text {Vitamin } \\
\mathrm{B}_{12}\end{array}$ & $\begin{array}{c}\text { DL-メチ } \\
\text { オニン } \\
\text { DL- } \\
\text { methi- } \\
\text { onine }\end{array}$ & $\begin{array}{c}\text { リジン } \\
\text { L- } \\
\text { Lysine }\end{array}$ & $\begin{array}{l}\text { グリシン } \\
\text { Glycine }\end{array}$ & $\begin{array}{l}\text { その他 } \\
\text { Others }\end{array}$ \\
\hline $\mathrm{C} P \quad(\%)$ & 9.2 & 44.4 & 14.5 & & 63.0 & 59.0 & & 100 & 100 & 100 & \\
\hline TDN $(\%)$ & 78.5 & 56.2 & 49.5 & 218.0 & 68.4 & $\begin{array}{l}66.0 \\
77.0 \\
\end{array}$ & & 100 & 100 & 100 & \\
\hline $\begin{array}{c}\text { 赛験 } \\
\text { Expt. } \\
1 \text { 区 } \\
{ }_{1}\end{array}$ & $\begin{array}{r}\% \\
70.2\end{array}$ & $\begin{array}{r}\% \\
9.5\end{array}$ & $\begin{array}{r}\% \\
0.06\end{array}$ & $\begin{array}{r}\% \\
0.2\end{array}$ & $\%$ & $\begin{array}{c}\% \\
15.0 \mathrm{a}\end{array}$ & $\%$ & $\begin{array}{r}\% \\
0.1\end{array}$ & $\%$ & $\%$ & $\begin{array}{r}\% \\
4.94\end{array}$ \\
\hline 2 & 68.2 & 9.8 & 0.45 & 1.5 & & $15.0 \mathrm{~b}$ & 0.01 & 0.1 & & & 4.94 \\
\hline 3 & 70.5 & 4.7 & 1.75 & & 3.0 & $15.0 \mathrm{a}$ & 0.01 & 0.1 & & & 4.94 \\
\hline 4 & 70.8 & 5.1 & 0.16 & 0.9 & 3.0 & $15.0 \mathrm{~b}$ & & 0.1 & & & 4.94 \\
\hline 5 & 70.2 & 9.5 & 0.05 & 0.2 & & $15.0 \mathrm{a}$ & 0.01 & 0.1 & & & 4.94 \\
\hline 6 & 68.2 & 9.8 & 0.46 & 1.5 & & $15.0 \mathrm{~b}$ & & 0.1 & & & 4.94 \\
\hline 7 & 70.5 & 4.7 & 1.76 & & 3.0 & $15.0 \mathrm{a}$ & & 0.1 & & & 4.94 \\
\hline & 70.8 & 5.1 & 0.15 & 0.9 & 3.0 & $15.0 \mathrm{~b}$ & 0.01 & 0.1 & & & 4.94 \\
\hline $\begin{array}{c}\text { 対 照 区 } \\
\text { Control }\end{array}$ & 61.0 & 26.9 & 0.86 & 3.2 & 3.0 & & & 0.1 & & & 4.94 \\
\hline $\begin{array}{c}\text { 実験 } \\
\text { Expt. }{ }^{3} \\
1 \text { 区 }\end{array}$ & 70.2 & 9.5 & 0.06 & 0.2 & & $15.0 \mathrm{a}$ & & 0.1 & & & 4.94 \\
\hline 2 & 69.95 & 9.0 & 0.61 & 0.2 & & $15.0 \mathrm{a}$ & & 0.2 & 0.1 & & 4.94 \\
\hline 3 & 70.05 & 9. 31 & 0.29 & 0.2 & & $15.0 \mathrm{a}$ & 0.01 & 0.1 & 0.1 & & 4.94 \\
\hline 4 & 70.05 & 9.31 & 0.29 & 0.2 & & $15.0 \mathrm{a}$ & 0.01 & 0.2 & & & 4.94 \\
\hline 5 & 69.95 & 9.0 & 0.61 & 0.2 & & $15.0 \mathrm{a}$ & & 0.1 & 0.1 & 0.1 & 4.94 \\
\hline 6 & 69.95 & 9.0 & 0.61 & 0.2 & & $15.0 \mathrm{a}$ & & 0.2 & & 0.1 & 4.94 \\
\hline 7 & 70.05 & 9.31 & 0.29 & 0.2 & & {$[5.0 \mathrm{a}$} & 0.01 & 0.1 & & 0.1 & 4.94 \\
\hline 8 & 69.84 & 8.7 & 0.91 & 0.2 & & $15.0 \mathrm{~b}$ & 0.01 & 0.2 & 0.1 & 0.1 & 4.94 \\
\hline $\begin{array}{l}\text { 対 照 区 } \\
\text { Control }\end{array}$ & 61.0 & 26.9 & 0.86 & 3.2 & 3.0 & & & 0.1 & & & 4.94 \\
\hline
\end{tabular}

1）炭化水素酵母の $\mathrm{a}$ と $\mathrm{b}$ は同一のもので，aでは TDN 含量を $77 \%, \mathrm{~b}$ ではTDN含量を $66 \%$ で計算配合した。 Total digestible nutrients of the same hydrocarbon yeast with sign $a$ and $b$ was estimated to be $77 \%$ and $66 \%$, respectively.

2) $1 \mathrm{~kg}$ 中に, ビタミン $\mathrm{B}_{12} 500 \mathrm{mg}$ を含む。

Containing $500 \mathrm{mg}$ of cyanocobalamin in one $\mathrm{kg}$.

3）その他には次のものを含む。

アルファルファミール $2 \%$ (CP $17.5 \%, \operatorname{TDN} 24 \%)$, 炭酸カルシウム $1.5 \%$, 第 3 リン酸カルシウム $0.5 \%$, 食塩 $0.45 \%$ ，微量無機物混合剒 $0.05 \%$ ( Mn $8 \%, \mathrm{Zn} 5 \%, \mathrm{Fe} 0.6 \%, \mathrm{I} 0.1 \%, \mathrm{Cu} 0.06 \%$ を含む), ビタミ ン $\mathrm{B}$ 群郩 $0.2 \%\left(1 \mathrm{~kg}\right.$ 中に $\mathrm{B}_{1} 2 \mathrm{~g}, \mathrm{~B}_{2} 10 \mathrm{~g}, \mathrm{~B}_{6} 2 \mathrm{~g}$, 塩化コリン $138 \mathrm{~g}$, ニコチン酸 $2 \mathrm{~g}$, パントテン酸カル シウム $4.35 \mathrm{~g}$, 葉酸 $1 \mathrm{~g}$ を含む), ビタミン $\mathrm{A}, \mathrm{D}, \mathrm{E}$ 唷 $0.1 \%$ ( $1 \mathrm{~g}$ 中に, A 10,000 I.U., $\mathrm{D}_{3} 2,000$ I.U., E 10 I.U. を含む)，抗生物質製戍 $0.1 \%$ ( $1 \mathrm{~g}$ 中に，スピラマイシン $20 \mathrm{mg}$ を含む)，コクシジウム子防刘 $0.04 \%$ ( $1 \mathrm{~g}$ 中に, デコキネイト $100 \mathrm{mg}$ を含む)。

Others composed of $2 \%$ of alfalfa meal, $1.5 \%$ of $\mathrm{CaCO}_{3}, 0.5 \%$ of $\mathrm{Ca}_{3}\left(\mathrm{PO}_{4}\right)_{2}, 0.45 \%$ of $\mathrm{NaCl}, 0.05 \%$ of trace mineral supplement, $0.2 \%$ of vitamin B supplement, $0.1 \%$ of vitamin A, D, E supplement, $0.1 \%$ of spiramycin supplement and $0.04 \%$ of coccidiostat. Trace mineral supplement composed of $8 \%$ of $\mathrm{Mn}, 5 \%$ of $\mathrm{Zn}, 0.6 \%$ of $\mathrm{Fe}, 0.1 \%$ of $\mathrm{I}, 0.06 \%$ of $\mathrm{Cu}$. Vitamin B supplement containing in one $\mathrm{kg}$, thiamine $2 \mathrm{~g}$, riboflavin $10 \mathrm{~g}$, pyridoxine $2 \mathrm{~g}$, choline chloride $138 \mathrm{~g}$, niacin $2 \mathrm{~g}$, Ca-pantothenate $4.35 \mathrm{~g}$ and folic acid $1 \mathrm{~g}$. Vitamin A, D, E supplement containing in one g, vitamin A 10,000 I.U., vitamin $\mathrm{D}_{3}$ 2,000 I.U., vitamin E 10 I.U.. Spiramycin supplement containing in one g, spiramycin $20 \mathrm{mg}$. Coccidiostat containing in one $\mathrm{g}$, decokinate $100 \mathrm{mg}$. 
は $80 \%$ ，実験 II では $77 \%$ と66\%，実験 III では $77 \%$ と タなした。これは岡山における酵母の分析值 CP 60\%と 農林省畜産試験場に㧍ける酵母の代謝エネルギー（ME） 測定值 ${ }^{3)}$ ，すなわち，実験 I に供試した酵母之同一ロッ トの ME 測定值, 乾物 $1 \mathrm{~g}$ 当たり $3.39 \mathrm{kcal}$ から推定 したものである。

実験 I，II および III に供試した前，後期の飼料組成 をすべて表示することは省略し，代表として実験】およ び IIII後期用飼料の組成のみを表 1 亿示した。

実験 I およびIIIの前期用飼料の組成は，基本的には表 1 の組成と同じであるが，つぎの 2 点のみが異なってい る。古なわち, 実験 IIにおける魚粉の添加量は, 後期用 の3\%に対し前期用では $5 \%$ とした。また, 表 1 注 3 の うち第 3 リン酸カルシウムを $2 \%$ に, 食塩を $0.5 \%$ に 微量無機物混合剂を $0.1 \%$ に, それぞれ増加した。これ らの増加にともなう補正は，とうもろこし，大豆粕，ら 一をなよび大豆油の含量を調節して行なった。

実験 I では, 酵母の配合量, 飼料の CP, TDN が異 なるぶ, 表 1 に同様な組成で, とうもるこし, 大豆粕, ふな⿻, 大豆油およびューンスターチの含量を調節して 酵母を $10 ， 15$ および $20 \%$ 配合した。この場合，前，後 期用とも酵母 10 および $15 \%$ 添加区では, 魚粉の全量と 大豆粕の一部を，また，酵母 $20 \%$ 添加区では，魚粉お よび大豆粕の全量を，それぞ酵母で扮きかえることに なった。

実験計画およびデータの統計的解析：実験 I では，酵 母の配合量を因子として取り上げ，0，10，15および 20 \%の4 水準とし，性別をブロック因子として組合せた 8 試験区について乱塊法実験を行なった。データは乱塊法 として解析した後, 増体量と酵母配合量との関係につい て回帰分析を行なった。

実験 II では，酵母の形状，魚粉の添加，酵母 TDN の 評価およびビタミン $\mathrm{B}_{12}$ の添加の 4 因子を取り上げ， $\mathrm{L}_{8}$ 直交表11)の第 $1 ， 2 ， 4$ 抢よび 7 列にそれぞれわりつけ た。形状因子はペレットかマッシュの 2 水準, TDNの 評価は $77 \%$ と $66 \%$ の 2 水準, 魚粉とビタミン $\mathrm{B}_{12}$ とは 添加, 無添加の 2 水準とし, 添加量は表 1 に示した。別 に酵母岂含まない対照飼料空設け，合計 9 種類の飼料因 子（A）に性別因子（S）を組合せた 2 元配置法実験計 画を, 岡山, 広島の 2 ブロック（B）で行なう乱塊法と 組合せた 2 元配置法とした。

データの解析には，まず乱塊法としてブロック因子と 乱塊法の誤差 $(\mathrm{B} \times \mathrm{AS}$ で示される) を区分し，ついで 2 元配置法として 飼料（A）と性別（S）の主効果と交 互作用 $(\mathrm{A} \times \mathrm{S})$ を求めた。飼料の主効果は対照飼料と 酵母飼料の比較を区分した上で，酵母飼料について $\mathrm{L}_{8}$
直交表として YATES の算法11)で, 形状, 魚粉, TDN 評価打よびビタミン $\mathrm{B}_{12}$ の 4 因子の効果を検討した。

実験 III では, グリシン, ビタミン $\mathrm{B}_{12}$, メチオニンお よびリジンの 4 因子を取り上げ， $\mathrm{L}_{8}$ 直交表の第 $1,2,4$ および 7 列にそれぞれわりつけた。メチオニンを除く 3 因子は，それぞれ添加，無添加の 2 水準とし，添加量は 表 1 に示した。メチオニンは添加量を 0.1 および $0.2 \%$ とする2水準とした。別に酵母を含まない対照飼料を設 け，実験 II の場合と同様に9 種類の飼料 (A), 性別( S ) および岡山, 広島, 島根の3ブロック（B）による乱塊 法と組合せた 2 元配置法とした。

データの解析は，実験 II の場合と同様にして行ないた が, 刘照飼料と酵母飼料の比較ではなく, 刘照飼料とビ タミン $\mathrm{B}_{12}$ を添加した酵母飼料の比較を行なった。

供試品：この実験に供試した酵母は，nーパラフィンを 炭素源として培養生庵されたもので， $\mathrm{CP}$ が $60 \%$ （水分 $6 \%$ の場合), $\mathrm{ME}$ が乾物 $1 \mathrm{~g}$ 当たり $3.39 \mathrm{kcal} の も の$ を協和醗酵工業株式会社から求めた。酵母はそのまま使 用したが，実験 Iにおける酵母のペレットは同一ロット の酵母を加水加压後乾燥した直径 $2 \mathrm{~mm}$ のもので, 4 週 齢の後期用飼料から飼料中に配合した。

ビタミン $\mathrm{B}_{12}$ 剂は製品 $1 \mathrm{~kg}$ 中にビタミン $\mathrm{B}_{12}$ を 500 $\mathrm{mg}$ 含有のものを用いたが，実験 I では添加せず，実験 III IIIではビタミン $\mathrm{B}_{12}$ 添加区へ前後期とも添加した。 Lーリジン，グリシン㧍よび DLーメチオニンは純度 $98 \%$ 以上のものを用いた。魚粉は上質のペルーミールで, CP を63\%，TDNを68.4\%とみなして用いた。

供試飼料の分析方法：この実験に用いた酵母と飼料の 分析法は各実験とも常法 ${ }^{12)}$ によるほ，脂肪については 塩酸加水分解処理 ${ }^{13}$ ) (塩酸 $25 \mathrm{~m} l$ と水 $11 \mathrm{~m} l$ を加えた 比重 1.125 の塩酸で湯浴 40 分分解処理) 後, 霄法によ るエーテル抽出も行なった。

\section{実 験 結 果}

この実験に用いた酵母と飼料について，風山で供試し たものを分析したが，酵母の分析結果を表 2 に示した。 酵母のCP は 59.5 から $60.9 \%$ で，各実呀の設計にあた り酵母の CP $59 \%$ となしたことは，ほぼ適正であ のたと考えられる。また, 各実験に打ける酵母の栄養素 含量はロットが異なってもほぼ同じであった。

実験 I に供試した酵母と同一ロット酵母の ME は，農 林省畜産試験場の測定值 ${ }^{3}$ では乾物 $1 \mathrm{~g}$ 当たり, 産卵鷄

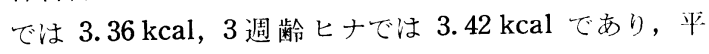
均では $3.39 \mathrm{kcal}$ であった。この数值から TDN は 81. $0 \%$ 程度と推定され, 水分 $5 \%$ の場合に注酵母の TDN が $77 \%$ 程度と推定された。また，酵母の粗脂肪は塭酸 
表 2. 炭化水素醉母の分析值

Table 2. Chemical Composition of Hydrocarbon yeasts tested

\begin{tabular}{|c|c|c|c|c|c|c|c|}
\hline \multirow{2}{*}{\multicolumn{2}{|c|}{$\begin{array}{c}\text { 炭 化 水 素 酥 船 } \\
\text { Hydrocarbon yeasts }\end{array}$}} & \multirow{3}{*}{$\begin{array}{c}\begin{array}{c}\text { 水 分 } \\
\text { Moisture }\end{array} \\
6.8 \%\end{array}$} & \multirow{3}{*}{$\begin{array}{c}\frac{\text { 粗蛋白質 }}{\begin{array}{c}\text { Crude } \\
\text { protein }\end{array}} \\
59.5 \%\end{array}$} & 粗 脂 & 肪 & \multirow{3}{*}{$\begin{array}{c}\begin{array}{c}\text { 粗 繊 維 } \\
\text { Crude fiber }\end{array} \\
3.4 \%\end{array}$} & \multirow{3}{*}{$\begin{array}{c}\begin{array}{c}\text { 粗 灰分 } \\
\text { Crude ash }\end{array} \\
7.3 \%\end{array}$} \\
\hline & & & & \multicolumn{2}{|c|}{ Crude fat $^{1}$} & & \\
\hline 実験 I Expt. 1 & マッシュ Mash & & & $2.0 \%$ & $8.2 \%$ & & \\
\hline 実験 II Expt. 2 & マッシュ Mash & 6.9 & 60.4 & 2.0 & 8.4 & 3.0 & 6.5 \\
\hline & ペレット Pellet & 7.5 & 60.6 & 1.6 & 7.7 & 3.5 & 5.4 \\
\hline 実験 III Expt. 3 & マッシュ Mash & 4.4 & 60.9 & 0.9 & 8.1 & 3.8 & 6.7 \\
\hline
\end{tabular}

1) 塩酸（塩酸 $25 \mathrm{~m} l+$ 水 $11 \mathrm{~m} l$, 此舟 1.125 ) で湯浴 40 分分解後, エーテル抽州した数值を示す。 Extracted with ether after hydrolysis with $\mathrm{HCl}$ of 1.125 specific gravity for 40 min..

で㷙処理すると常法分析に比べてかなり多く抽出でき， 酵母には $8 \%$ 程度の粗脂肪があることが悐められた。し たがって，各実験に供試した飼料の粗脂肪も常法分析に 比べて $2 \%$ 程度多く抽出できた。

飼料の CP 分析值をみると, 前期用飼料において実験 I では 20.3〜20.7\%，実験 II では 22.1〜23.1\%，実験 IIIでは 22.0〜22.5\%，また，後期用飼料において実験 I では 18.4〜 19.6\%，実験 II では 20.8〜21.0\%，実駗 IIIでは 20.2 20.8\% であり, 各実験とも各区閒の CP はほぼ一定しており，設計にあたっての推定值とほぼ同 じであった。

実験 I：慨付けから 10 週歯までの 1 羽平均増体量, 同 飼料摂取量および飼料要求率を表 3 に示したが，酵母の 添加量が増加与るにしたがって飼料撕取量打よび増体量 が減少与る傾向を示した。飼料要求率においては雄では あまり差がなかったが，雌では酵母多給区がわずかに少 った。

次に, 餌付けから 10 週齢までの增体量について 分散 分析し， F 検定したが酵母の添加と無添加区間において $1 \%$ 水準で有意差が認められた。また，酵母添加区間に おいては図 1 の回帰で, 酵母の添加量が増加寸るにした がって增体量が直線的に減少した。

実験 II：慨付けから 10 週龄までの飼料提取量, 増体 量および飼料要求率を分散分析した結果は表 4 に示した とおりであるが，飼料摈取量に関する $\mathrm{C} \times \mathrm{D}, \mathrm{E} \times \mathrm{F}$ 交 互作用が $5 \%$ 水準で有意であったほが，交広作用が有 意ではないので，各因子の水準ごとに平妇值を求め，そ の結果を表 5 に示した。

飼料摂取量における魚粉とビタミン $\mathrm{B}_{12}$ の交互作用 は， $\mathrm{C} \times \mathrm{D}$ と $\mathrm{E} \times \mathrm{F}$ が重なったものであり，いずれが有 意なのか, いずれも有意なのか統計的に区別することは できないが, $\mathrm{E} \times \mathrm{F}$ につてみるとF因子は酵母の TDN の評価という抽象的な因子であり，E因子のペレット化 という具体的な行為の効果が，TDNをどのように評価
表 3. 实駘 I の成績 $(0 \sim 10$ 週齢 $)$

Table 3. Effect of feeding Hydrocarbon yeasts (Expt. 1, 0 10 wks)

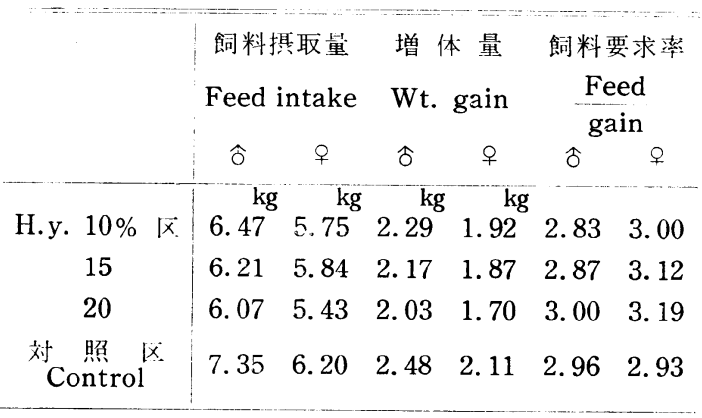

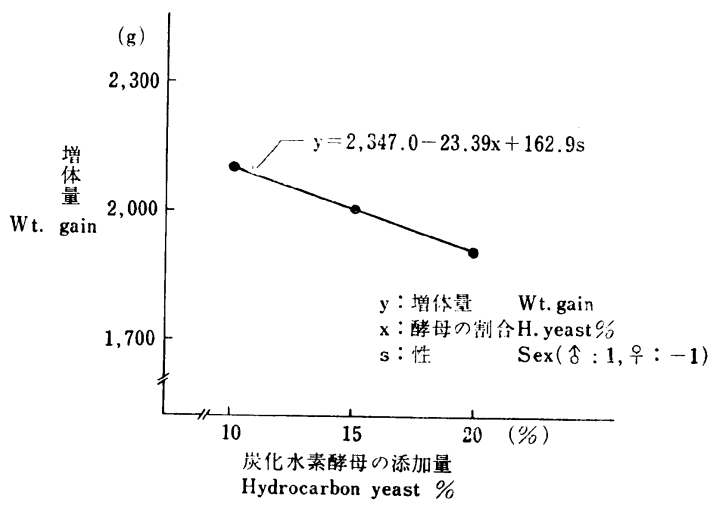

仪 1. 増体量と酵母添加量との関係 $(0 \sim 10$ 週龄)

Fig. 1. Wt. gain and Hydrocarbon yeast \% (Expt. 1, $0 \sim 10$ wks)

したかによって变ることは栄貝学的に考えにくいので， $\mathrm{E} \times \mathrm{F}$ の交互作用はありえないと考无られる。たがっ て，この交互作用が有意であるということは $\mathrm{C} \times \mathrm{D}$ が有 意であること走子ものと判断される。

そこで, $\mathrm{C} \times \mathrm{D}$, 古なわち魚粉とビタミン $\mathrm{B}_{12}$ の添加 の有無により表4のとおりわりつけした因子別に平均值 
多田・古市・妹尾・番氐・山中・岩瀬・八幡：炭化水素酵母のブロイラーへの給与

表 4. 乱塊 $\mathrm{L}_{8}$ 直交表の分散分析表（実験 II )

Table 4. Variance analyses of randomized block design and $\mathrm{L}_{8}$ tables of orthogonal arrays (Expt. 2)

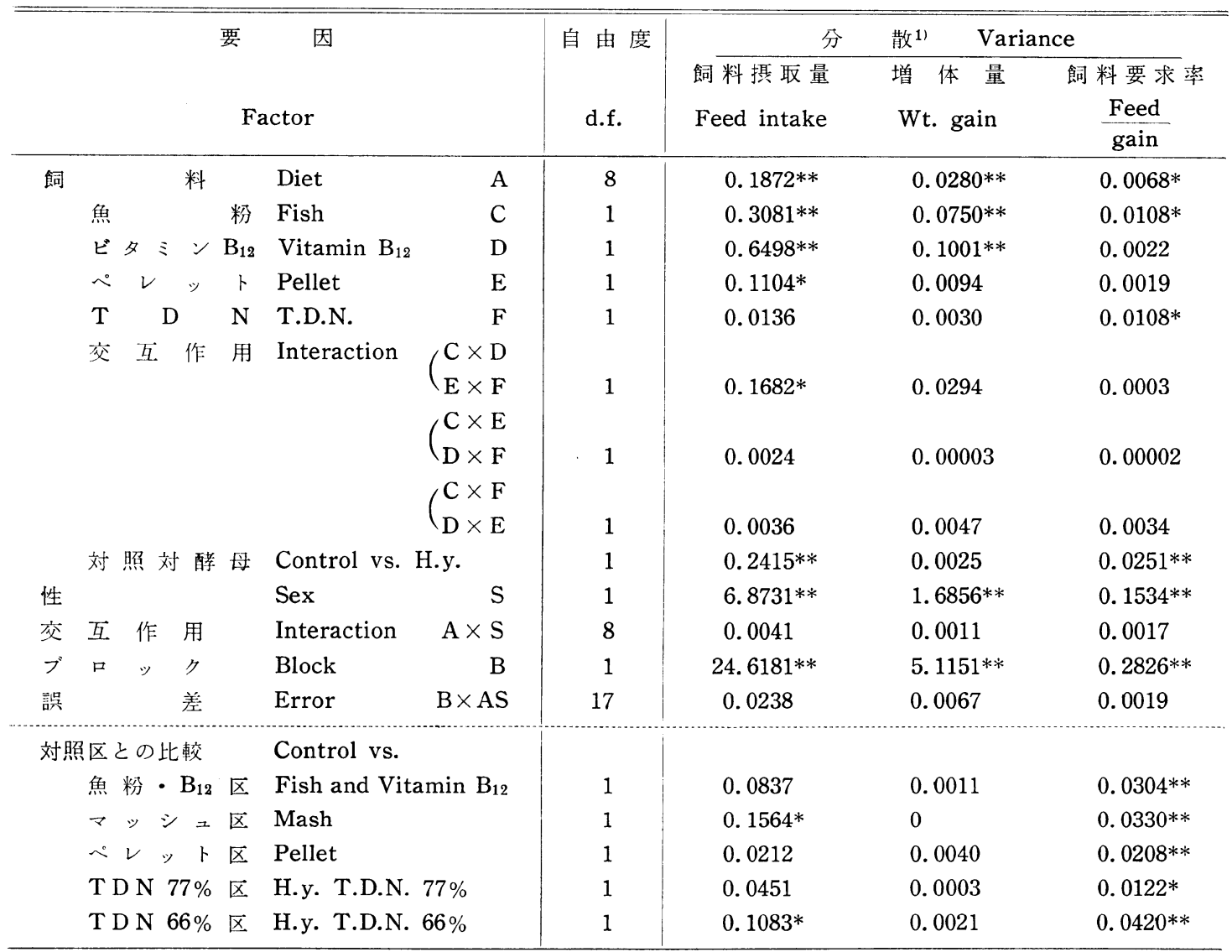

1) 飼料㠌取量, 増体量の単位は kg.

The unit of feed intake and body weight gain are $\mathrm{kg}$.

*: $5 \%$ 水準で有意, **: $1 \%$ 水準で有意.

*: Significant at $5 \%$ level, **: Significant at $1 \%$ level.

を求めて, 平均值間の比較を行なったが, この場合, 魚 粉とビタミン $\mathrm{B}_{12}$ の各因子の効果をそれぞれ単独に取り 上げて検討することは妥当でないので魚粉とビタミン $\mathrm{B}_{12}$ を一括して処理した。

飼料摂取量においては, 無添加 $(1,6$ 区) に比べて魚 粉単独添加 $\left(4,7\right.$ 区) で $0.34 \mathrm{~kg}$, ビタミン $\mathrm{B}_{12}$ 単独添 加 (2, 5 区) で $0.43 \mathrm{~kg}$ 増加し, 魚粉単独がわずかに 少なかったが，いずれも $1 \%$ 水準で有意であった。また， 両者を併用 $(3,8$ 区) すると $0.48 \mathrm{~kg}$ の増加で, これ もほぼ同程度の効果を示し，1\%水準で有意であった。 これは魚粉とビタミン $\mathrm{B}_{12}$ とはいずれか一方があればよ く，併用してもそれ以上の効果を示さないことを意味す る。

魚粉とビタミン $\mathrm{B}_{12}$ の飼料摂取量に対する効果は, 増
体量にも反映している。つまり, 魚粉単独添加で 0.16 $\mathrm{kg}$, ビタミン $\mathrm{B}_{12}$ 単独添加で $0.18 \mathrm{~kg}$ 増加し, 雨者を 併用すると $0.21 \mathrm{~kg}$ の増加で，これもほぼ同程度の効果 を示し，1\%水準で有意であった。これは飼料㩒取量と 同じく，魚粉とビタミン $\mathrm{B}_{1}$ ～とはいずれか一方があれば よく，併用してもそれ以上の効果は示さないことを意味 する。

飼料要求率に対しては魚粉のみが有效で, 魚粉単独添 加で平均 0.04 低下させ, ビタミン $\mathrm{B}_{12}$ との併用では平 均 0.05 低下させ，いずれも $5 \%$ 水準で有意であった。 なお, ビタミン $\mathrm{B}_{12}$ 単独添加では有意ではないが, 飼料 要求率を 0.02 低下させており有効な傾向がみられた。 しかし，この魚粉とビタミン $\mathrm{B}_{12}$ のわずかな差は増体量 に影響するほどではなかった。 
表 5. 魚粉，ビタミン $\mathrm{B}_{12}$ 打よび酵母のペレット化と TDN の効果 $(0$ １0 週齢）

Table 5. Effect of Fish meal, Vitamin $\mathrm{B}_{12}$, Hydrocarbon yeast Pellets and H.y. T.D.N. on feeding H.y. ( $0 \sim 10$ wks $)$

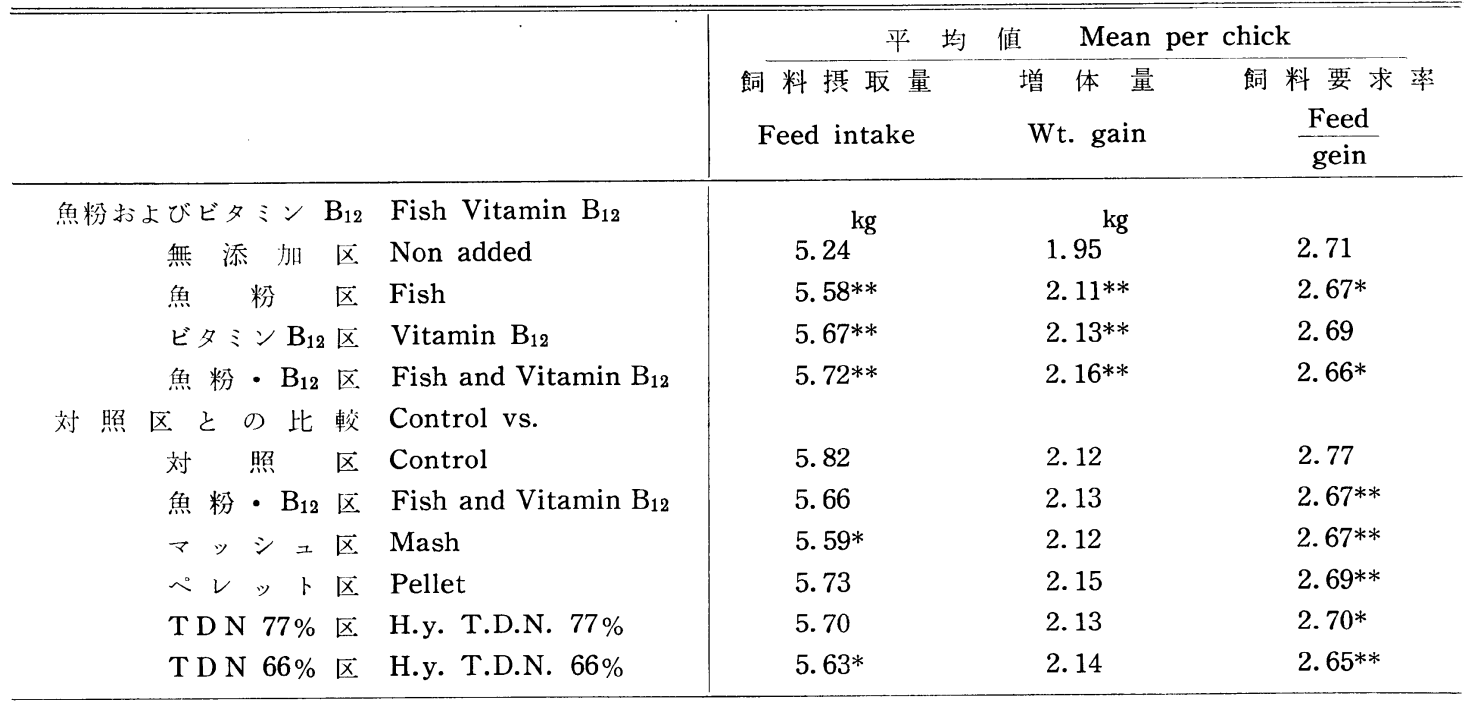

*: $5 \%$ 水準で有意, **: $1 \%$ 水準で有意。

*: Significant at $5 \%$ level, **: Significant at $1 \%$ level.

また，魚粉とビタミン $\mathrm{B}_{12}$ のいずれかもしくは両方を 含む区の平均と対照区とを比較すると，前者の飼料撕取 量が $0.16 \mathrm{~kg}$ 少なかったが，増体量は両者の間にほとえ ど差がなかった。しかし，飼料要求率では前者が 0.1 す ぐれ，1\% 水準で有意であった。

酵母のペレット化について, ペレット区 $(5,6,7,8$ 区）とマッシュ区 $(1,2 ， 3 ， 4$ 区）の比較をすると，前 者の飼料掑取量が $0.12 \mathrm{~kg}$ 多く（5\% 水準で有意）な り, 増体量が $0.03 \mathrm{~kg}$ 増加した。しふし, 飼料要求率の 差は前者がわずか 0.02 すぐれたのみであった。これを 魚粉とビタミン $\mathrm{B}_{12}$ のいずれかもしくは両方を含む場 合, すなわち, ペレット 3 区 $(5,7,8$ 区) とマッシュ 3 区 $(2 ， 3 ， 4$ 区) のそれぞれの平均值で比較すると, 前者の飼料摂取量が表 5 のように $0.14 \mathrm{~kg}$ 多くなり，増 体量が $0.03 \mathrm{~kg}$ 増加させたが, 飼料要求率においては前 者を 0.02 低下させている。

また，魚粉とビタミン $\mathrm{B}_{12}$ のいずれかもしくは両方を 含兑ペレットとマッシュの各 3 区の平均值と対照区とを 比較すると，マッシュ区の飼料摂取量が $0.23 \mathrm{~kg}(5 \%$ 水準で有意）少なかったが，増体量は両区の間で差がな く, 飼料要求率はマッシュ区が 0.2 (1\% 水準で有意) すぐれた。ペレット区と対照区では，前者の飼料摂取量 が $0.09 \mathrm{~kg}$ 少なく増体量が $0.03 \mathrm{~kg}$ 多かったが，飼料 要求率は前者が 0.08 ( $1 \%$ 水準で有意) 卞ぐれた。

酵母の TDN 評価 $77 \%(1,3,5,7$ 区）と $66 \%(2$,
$4,6,8$ 区）の比較では，66\% 区の飼料要求率が $77 \%$ 区に比べて 0.04 (5\% 水準で有意) すぐれた。また, 魚粉とビタミン $\mathrm{B}_{12}$ のいずれかもしくは両方を含も場合 について, TDN $77 \%$ 区 $(3,5,7$ 区 $)$ と 66\%区（2, 4,8 区) の平均と対照区とを比較すると，表 5 のとお り飼料摂取量は $77 \%$ 区が $0.12 \mathrm{~kg}, 66 \%$ 区が $0.19 \mathrm{~kg}$ (5\% 水準で有意) それぞれ少ないにもかかわらず増体 量は両者ともわずかに多かった。飼料要求率は $77 \%$ 区 が 0.07 (5\% 水準で有意)，66\% 区が 0.12 (1\% 水準 で有意）それぞれすぐれた。

次に，性別と場間についてみると，いずれも大型と中 型の差により大差が検出されているが，これは当然予想 されることである。しかし，飼料と性别との交互作用 $(\mathrm{A} \times \mathrm{S})$ は有意でなく, 性別による酵母の各処理に対す る反応の仕方は相似している。

実験 III：10 週齢における対照区の体重は，岡山では 雄が $3 \mathrm{~kg}$, 雌が $2.26 \mathrm{~kg}$, 広島では雄が $1.96 \mathrm{~kg}$, 雌が $1.57 \mathrm{~kg}$, 島根では雄が $2.52 \mathrm{~kg}$, 雌が $2.06 \mathrm{~kg}$ であり, ほぼ大中小の 3 段階の数值を示した。分散分析の結果を 表 6 に示したが，交互作用が有意でないので各因子の水 準ごとに平均值を求め，その結果を表 7 に示した。

酵母を魚粉の全量とおきかえて 飼料中に $15 \%$ 配合し た場合, ビタミン $\mathrm{B}_{12}$ の添加 $(3,4,7,8$ 区) は無添加 $(1,2 ， 5 ， 6$ 区) に比べて 1 羽平均で飼料撰取量を 0.32 $\mathrm{kg}$, 増体量を $0.18 \mathrm{~kg}$ それぞれ増加させ, 飼料要求率 
多田・古市・妹尾・番匠・山中・岩瀬・八幡：炭化水素酵母のブロイラーへの給与

表 6. 乱塊 $\mathrm{L}_{8}$ 直交表の分散分析表（実験 III）

Table 6. Variance analyses of randomized block design and $\mathrm{L}_{8}$ tables of orthogonal arrays (Expt. 3)

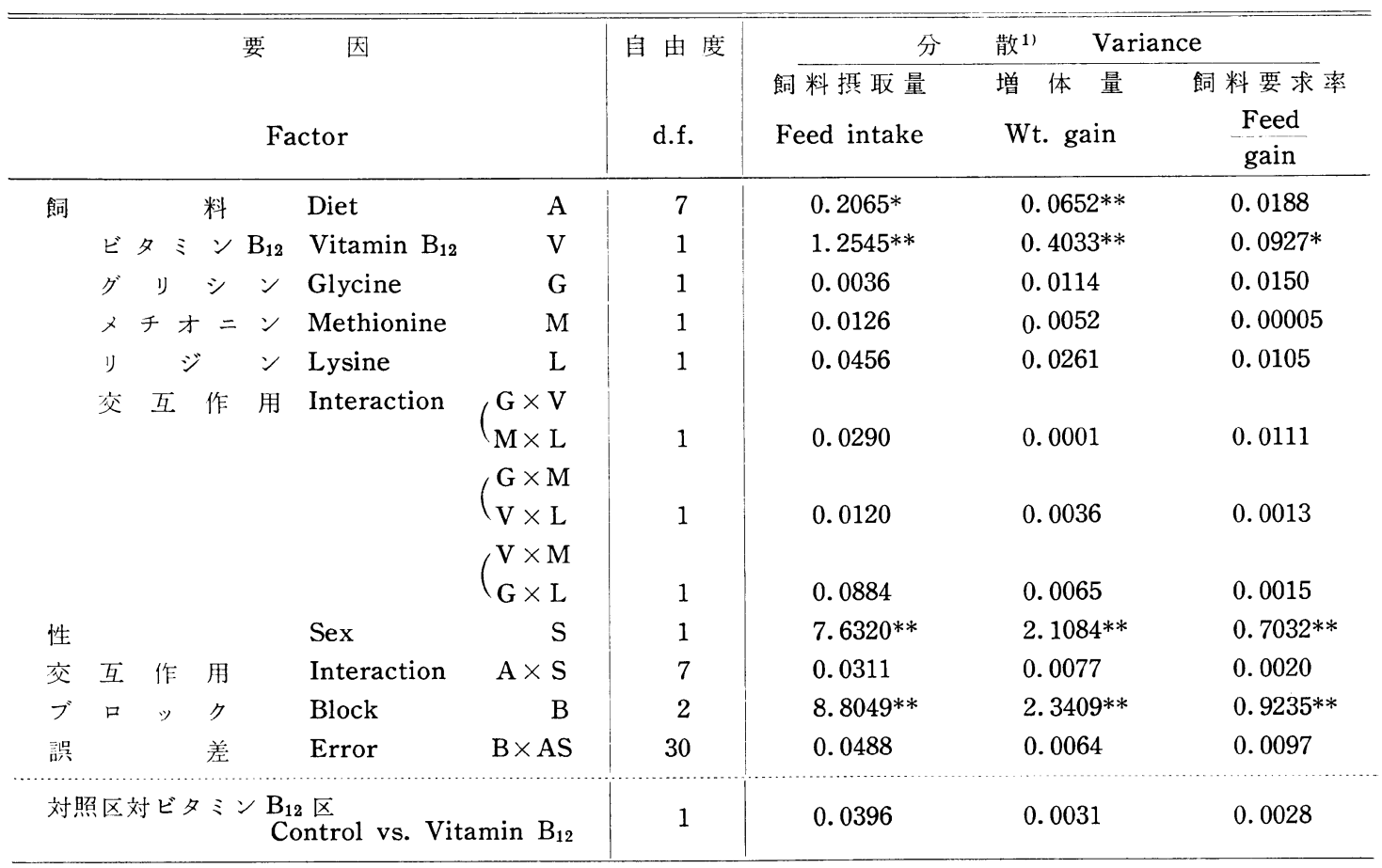

1) 表 4 の脚注参照。

See Footnote in Table 4.

表 7. ビタミン $\mathrm{B}_{12}$ とアミノ酸の効果 $(0 \sim 10$ 週齢 $)$

Table 7. Effect of Vitamin $B_{12}$ and Amino acid on feeding Hydrocarbon yeasts $(0 \sim 10$ wks $)$

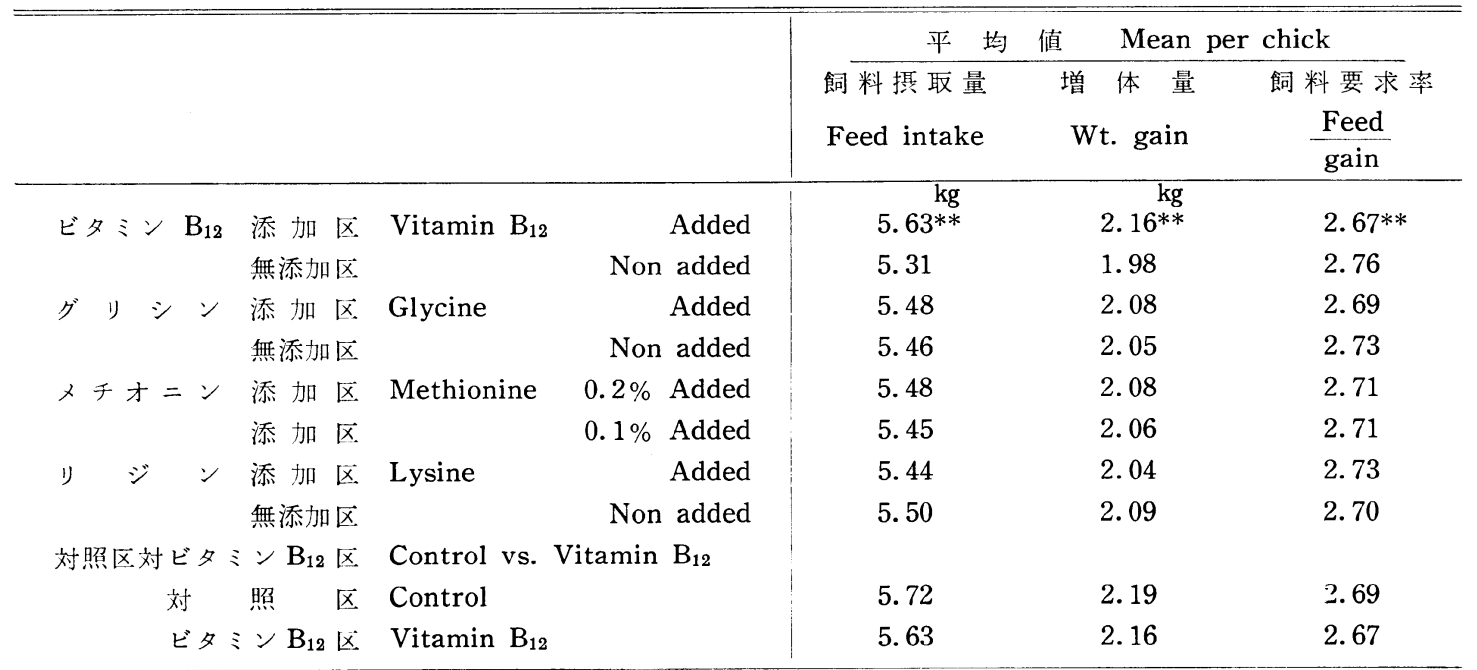

**: $1 \%$ 水準で有意。

$* *$ : Significant at $1 \%$ level. 
を 0.09 向上させており，いずれも $1 \%$ 水準で有意であ った。

グリシンとリジンの添加効果は飼料摂取量, 増体量, 飼料要求率のいずれにおいても有意でなかった。メチオ ニン $0.2 \%$ 添加区と $0.1 \%$ 添加区の間には, 飼料摂取 量, 增体量, 飼料要求率のいずれに抢いても有意な差が みられなかった。

ビタミン $\mathrm{B}_{12}$ 添加区と対照区を比較すると，前者の飼 料摂取量が $0.09 \mathrm{~kg}$, 堌体量が $0.03 \mathrm{~kg}$ それぞれ減少し ているが, 飼料要求率は 0.02 向上している。しかし, いずれも有意でなかった。したがって，魚粉の全量を醅 母でおきかえる場合でも, ビタミン $\mathrm{B}_{12}$ とメチオニン $0.1 \%$ 以上を添加すれば対照区とほぼ同じ成績が得られ るものといえる。

次に，性別と場間についてみると，いずれも大差が検 出されているが，場間差の大部分は供試ヒナの大中小の 差によるものと考元られる。しかし，飼料と性別との交 互作用 $(\mathrm{A} \times \mathrm{S})$ 法有意でなく, 性別による酵母の各処 理に対する反応の仕方は相似しており，この傾向は実験 IIの傾向と同じであった。

育成率：各実験における育成率を雄と雌の平均でみる と，実験 I では酵母 $10 \%$ 添加区と同 $15 \%$ 区がそれぞれ $96 \%$ ，同 $20 \%$ 区が $97 \%$ であり，対照区の $95 \%$ との間 に差がなかった。

実験 IIで最も劣った区は両場とも $94 \%$ であるが，醅 母全区 $(1 \sim 8$ 区 $)$ の平均では岡山が $97.5 \%$, 広島が 96.8\% であり，対照区との間に差がなかった。

実験 III で最も劣った区は岡山が $94 \%$ ，広島が $96 \%$ ， 島根が $88 \%$ であるが，酵母全区の平均では岡山が 97.8 $\%$, 広島が $98.5 \%$, 島根が $92.3 \%$ であり，3 場の酵母 全区の平均 $96.2 \%$ と対照区の $97 \%$ との間に差がなかっ た。

また，各実験における雄と雌の間，ブロック間に特別 な差はみられず，ヒナの健康状態む対照区との間に差が なかった。なお、へい死ヒナにおいては酵母の給与が要 因と考元られる肉眼的な病变は剖検の結果で注認められ なかった。

\section{考察}

実験 Iにおいて飼料中の魚粉の全量と大豆粕の一部も しくは全量を酵母でおきかえて，酵母飼料を多給する と,ブロイラーの増体量が著しく減少した。この原因を 究明する目的で行なった実験 II および III の成績によれ ば，ビタミン $\mathrm{B}_{12}$ を飼料 $1 \mathrm{~kg}$ 当たり $50 \mu \mathrm{g}$ の割合で添 加すれば，魚粉を含まない場合でも増体量はほぼ正常と なり，魚粉と大豆粕を主要な蛋白質源とする対照飼料の
給与区の成績とほぼ一致した。

したがって，実験 Iで認められた酵母多給による増体 量の減少は, 主としてビタミン $\mathrm{B}_{12}$ の不足によるもの々 判断される。すでに報告したように占，産卵鵎用飼料に おいても魚粉の全量をおきかえて酵母を多給する場合， ビタミン $\mathrm{B}_{12}$ の欠ミをおこし，産卵率に汢大きな影響を およぼさないが，ふ化率の著しい低下をひきおこした。

ビタミン $\mathrm{B}_{12}$ が不足すると, ヒナの発育の低下, ふ化 率の低下をおこすことはよく知られている14)。一方, 既 報) のように酵母のビタミン $\mathrm{B}_{12}$ 含量は $0.02 \mu \mathrm{g} / \mathrm{g}$ に すぎなかった。これらの知見から酵母の使用にあたり， 飼料中のビタミン $\mathrm{B}_{12}$ に配慮する必要があるといえる。

しかし，ビタミン $\mathrm{B}_{12}$ を添加しても酵母飼料の飼料摂 取量が対照飼料の摂取量より少なく，したがって飼料要 求率がすぐれる傾向が認められ, 醉母にはビタミン $\mathrm{B}_{12}$ が少ない以外に，飼料摂取量を抑制する要因が含まれる ことが示唆されている。しかし，これは飼料効率の向上 を意味し，産業上はむしろ好ましい効果といえる。

実験 IIにおいて，魚粉の添加がビタミン $\mathrm{B}_{12}$ の添加之 同様な効果があり，両者を併用しても，それぞれ単独て 添加した場合と同程度の効果があることが認められた。 この知見は魚粉がビタミン $\mathrm{B}_{12}$ の豊富な給源であり ${ }^{44)}$, しかも, ビタミンは必要量以上の過剩量を与えても特別 な効果を示さないことから十分予想されることであり， 酵母多給による増体量の隇少が主としてビタミン $\mathrm{B}_{12}$ の 不足によるという前述の述見と矛盾しないといえる。

実験亚の結果からビタミン $\mathrm{B}_{12}$ を添加すれば，魚粉を 含む対照区とほぼ同じ成績となることが確認されたの で，魚粉の効果はそれれに含まれるビタミン $\mathrm{B}_{12}$ のみの効 果といえるであろう。

酵母中のアミノ酸のうら不足の傾向が考えられた，グ リシン,リジンの添加は有効でなく, メチオニンの添加 は $0.1 \%$ 以上にする必要はないことが認められた。

酵母をペレット化することにより飼料摂取量が増加す るが，増体量や飼料要求率にはマッシュとの間に大差を 生じないので, ペレット化の可否は，そのために要する 経費，そのために生ずる利点，すな和ち，取扱いやすさ， ほこりつ济くないなども含めて, 総合的に判断しなけれ ばならない。またペレット化しても対照区より飼料拱 取量が少ない（有意ではない）ので，マッシュであるこ とが飼料撕取量低下の唯一の原因ではない。

酵母の TDN 評価量 $77 \%$ と $66 \%$ の比較は, 酵母の ME $3.39 \mathrm{kcal} / \mathrm{g}$ (TDN に換算して 77\% ${ }^{15)}$ が, 外国の データ1,4) に比べて過大ではないかという疑問を検討す ることを目的としている。試験飼料の TDN が一定にな るように設計しているので，酵母の TDN 評洒 量 77\% 
之 $66 \%$ のうち, 真值に近い区では，他の条件が一定な らば対照区の成績とほぼ同じものとなるはずである。 また，一方過大に評価した区では飼料のTDN は，1. $65 \%$ （酵母の配合量 $15 \% \times$ 過大評価量 0.11 ）だけ低く なり，乙たがって飼料摂取量は多く，飼料要求率も大き くなるはずである。また，過小に評価した場合は，この 逆となるはずである。かりに酵母の TDN 評洒量 $66 \%$ ぶ真值に近いとすれば，77\% 区は過大評価であるから 実際の飼料のTDN が 1.65\% 低いため，対照区に比べ て飼料摃取量は多くなり, 飼料要求率は大きくなるはず である。ところが, 実際において梳対照区に比べて $77 \%$ 区の飼料摂取量が $0.12 \mathrm{~kg}$ 少なく, 飼料要求率は 0.07 だけ小さくなって抢り，予想と全く逆であった。乙たが って，酵母の TDN $66 \%$ という評価は兄しろ過小評価 であるといえる。

逆に, TDN 評価量 77\% が真值に近いとす玌ば, $66 \%$ 消過小評価となる。実際に注対照区に比べて $66 \%$ 区の 飼料摂取量は $0.19 \mathrm{~kg}$ 少なく, 飼料要求率は 0.12 低い。 いずれも有意であって明らかに過小評価といえる。した がって，TDN 77\% の評価量が真值に近いといえ，酵母 の ME $3.39 \mathrm{kcal} / \mathrm{g}$ は過大評価ではないかという疑いは 否定できるであろう。

なお，対照区，77\%区，66\%区のいずれにおいても， 増体量に大差注認められなかった。鶏には飼料エネルギ 一含量に応じて飼料摂取量を調節する能力があり, TDN 評価量の差 $1.65 \%$ の差は，この能力によって打消され， 増体量には反映しなかったものと考えられる。

対照区と酵母区との比較では，魚粉またはビタミン $\mathrm{B}_{12}$ の添加により, 酵母の TDN 評価量 $77 \%$ の場合で も，その効果が十分期待できた。

以上の考察と前報 ${ }^{6)}$ の結果ををとめると，つぎのよう な結論が導かれる。すなわち, 酵母を養䳕用飼料の主要 蛋白質源として，穀類に配合する場合，含硫アミノ酸と ビタミン $\mathrm{B}_{12}$ が不足するおそれがあり，十分注意する必 要がある。この場合，飼料中 $0.1 \%$ のメチオニン, 50 $\mu \mathrm{g} / \mathrm{kg}$ のビタミン $\mathrm{B}_{12}$ を添加すれば，ブロイラーの発 育は正常であった。含硫アミノ酸とビタミン $\mathrm{B}_{12}$ が不足 するという酵母の栄養学上の特徵は, 大豆粕の特徵と類 似しており，したがって，実用にあたり大豆粕の場合と 同様な配慮をすればよいといえる。

\section{要 約}

炭化水素酵母（以下, 酵母と略す）の飼料価值を明ら かにするため, n一パラフィンを炭素源として培養生産さ れた酵母を 1969 年から 1971 年まで 3 か年間ブロイラー に給与し, 岡山, 広島, 島根の 3 県により共同研究を行
なった。

この実験注，実験 I では酵母.多給効果を，実験 II で は魚粉とビタミン $\mathrm{B}_{12}$ の添加, 酵母のペレット化, 酵母 の TDN 評価の 4 因子を取り上げ，実験 III ではグリシ ソ,リジン，メチオニンおよびビタミン $\mathrm{B}_{12}$ の 4 因子の 効果を検討した。

供試ヒナは各実験とも雄雌同数とし，実験 I ではブロ イラー専用種雄雌各 200 羽, 実験 II では同雄此各 450 羽，実験 III では同雄雌各 675 羽をそれぞれ用い，餌付 けから 10 週齢まで実施した。なお，実験 II，III につい ては $L_{8}$ 直交表の実験計画にしたがって実施し, 次の成 績を得た。

1. 飼料中の魚粉の全量と大豆粕の一部もしくは全量 を酵母でおきかえて，酵母を $10 ， 15$ および $20 \%$ 給与す ると, ブロイラーの増体量は酵母の添加量が増加するに したがって，直線的に低下した。しかし，このこと沖魚 粉またはビタミン $\mathrm{B}_{12}$ を添加することにより解決した。 この場合における魚粉の効果はその中に含まれるビタミ ン $\mathrm{B}_{12}$ によるものであることが認められた。以上のこと から飼料中の魚粉の全量と拈きかえて酵母を $15 \%$ 添加 した場合，ビタミン $\mathrm{B}_{12}$ を $50 \mu \mathrm{g} / \mathrm{kg}$ 添加することによ り, 対照飼料と差がなく, 前記酵母多給の問題点はビタ ミン $\mathrm{B}_{12}$ であり，それだけであったといえる。

なお，魚粉またはビタミン $\mathrm{B}_{12}$ の添加により, 飼料掑 取量を 1 羽平均で $0.32 \mathrm{~kg}$, 増体量を同 $0.18 \mathrm{~kg}$ 増加さ せ，飼料要求率を 0.09 向上させ，いず扎も $1 \%$ 水準で 有意であった。また，魚粉とビタミン $\mathrm{B}_{12}$ とはいずれか 一方があればよく, 两者を併用してもそれ以上の効果は 期待できないことが明らかとなった。

2. 酵母中に含まれるアミノ酸のうち不足の傾向が考 えられた，グリシン，リジンの各 $0.1 \%$ 添加は有効でな く,メチオニンの添加は $0.1 \%$ 以上にする必要はないこ とが認められた。

3. 酵母をペレット化することによりマッシュに比べ て飼料掑取量が 1 羽平均で $0.12 \mathrm{~kg}$ 増加 (5\% 水準で有 意）し，したがって増体量が $0.03 \mathrm{~kg}$ 増加したが, 飼料 要求率は前者が 0.01 すぐれたのみで，増体量，飼料要 求率とも两者の間に大差はみられなかった。

4. 酵母のエネルギー洒は，TDN として $66 \%$ と評 価することは過小評価であり， $77 \%$ の評価，すなわち， ME にして $3.39 \mathrm{kcal} / \mathrm{g}$ が真值に近いことが認められ た。

5. 各実験にお忷る育成率は, 酵母飼料と対照飼料と の間に差がなく，酵母多給の影響はみられなかった。ま た，へい死ヒナにおいて酵母の給与が要因と与えられる 肉眼的な病変注認められなかった。 


\section{謝辞}

この実施の実施にあたりご指導ご協力を賜わった農 林省畜産試験場栄養部飼料資源開発研究室長吉田実博士 ならびに試料の提供をいただいた協和醗醉工業株式会社 に対して，深甚の謝意を表する。

\section{文献}

1) Van Weerden E. J., C. A. Shacklady and P. VAN Der WaL: Brit. Poultry Sci., 11, 189, 1970.

2）西川哲三郎・田中庸雄・山根哲夫・本田博信：日 畜会報, 41，569， 1970.

3）星井 博 - 瀬恒 浩 - 吉田 実：家离会誌, 7, $147,1970$.

4) Waldroup, P.W., C.M. Hillard and R.J. Mitchell: Poultry Sci., 50, 1022, 1971.

5) Shannon D.W.F. and J.M. Mcnab: Brit. Poultry Sci., 13, 267, 1972.
6）多田昌男 - 妹尾交雄・村田武久・川崎 晃：家禽 会誌, 9, 17, 1972.

7）小坂清己・星井 博 - 吉田 実：同上， 9, 159, 1972.

8）吉田 実・生雲晴久 - 星井 博：同上, 9, 231, 1972.

9）執行交昭 -竹内昌昭：農化，46, 27, 1972.

10）吉田 実・多田昌男 - 番匠宏行 - 松島正洋・緒方 国幸・飯野雅夫・梅田 勲：家禽会誌，9，173， 1972.

11）吉田 実：飼料に関する実験計画法と成績のまと め方, p. 95, 日本科学飼料協会, 1968.

12）森本 宏 監修：動物栄養試験法, p. 280, 養賢 堂, 1971.

13）東京大学農学部農芸化学教室：改定新版実験農芸 化学上巻, p. 123 , 朝倉書店, 1966.

14) 森本 宏: 家畜栄養学, p. 397, 養賢堂, 1969.

15）吉田 実・星井 博 - 窪田大作：家禽会誌， 10, 18, 1973. 


\title{
Effect of Vitamin $B_{12}$ Supplementation to Hydrocabon Yeast on Growth of Broiler
}

\author{
Masao Tada ${ }^{1)}$, Hideshi Furuichi ${ }^{1}$, Fumio Seno'), Hiroyuki Bansho ${ }^{2}$, \\ Keizo Yamanaka ${ }^{21}$, Nobuo Iwase ${ }^{3)}$ and Sakuro Yahata ${ }^{31}$ \\ 1) Okayama Prefectural Poultry Experiment Station, Mitsu-machi \\ 2) Hiroshima Prefectural Livestock Experiment Station, Miyoshi-shi \\ 3) Shimane Prefectural Livestock Experiment Station, Izumo-shi
}

Three experiments were conducted to evaluate the effect of hydrocarbon yeast grown on $\mathrm{n}$-paraffin, as dietary protein source for broiler. The contents of crude protein, metabolizable energy and vitamin $\mathrm{B}_{12}$ in the yeast were $64 \%, 3.39 \mathrm{kcal} / \mathrm{g}$ and $0.02 \mu \mathrm{g} / \mathrm{g}$ on dry-basis, respectively.

In Expt. 1, all of fish meal and part or all of soybean meal in the control ration were replaced by the yeast at the dietary yeast level of 10,15 and $20 \%$, respectively. Body weight gain of the broiler at 10 weeks of age was in inverse proportion to the dietary yeast level. The relationship could be well described by the following equation:

$$
y=2,347-23.39 x+162.9 s
$$

where, $y$ is body weight gain $(\mathrm{g}), x$ is dietary yeast level (\%) and $s$ is a correction term for sex difference, being 1 for male and -1 for female.

In Expt. 2, 4 factors, i.e. supplementation of either vitamin $\mathrm{B}_{12}$ or fish meal, effect of pelleting of yeast and assesment of total digestible nutrients of yeast, being either 66 or $77 \%$, were studied on the effect to improve growth rate of broiler on hydrocarbon yeast. Supplementation of either vitamin $B_{12}$ or fish meal was effective to improve growth rate of broiler. Since the effect of both vitamin $\mathrm{B}_{12}$ and fish meal was not additive, the effect of fish meal was suspected to be due to vitamin $B_{12}$ content in it. Pelleting the yeast improved feed intake but it had little effect on growth rate. Total digestible nutrients in the yeast was assessed as $77 \%$, i.e. $3.39 \mathrm{kcal}$ of metabolizable energy per $g$ on dry-basis.

In Expt. 3, effect of supplemented vitamin $\mathrm{B}_{12}$, L-lysine, glycine and extra DLmethionine which had been added already at $0.1 \%$ level in all of the experimental diets, was compared. Only the supplementation of vitamin $B_{12}$ was effective to improve the performance of broiler, supporting the findings in Expt. 2. Actually, growth rate of the chicks on $15 \%$ yeast diet with supplementary vitamin $\mathrm{B}_{12}$ was almost identical to that on the control diet, of which main protein source was fish meal and soybean meal.

It was concluded that hydrocarbon yeast is lacking in sulfur amino acids and vitamin $\mathrm{B}_{12}$, resembling soybean meal as poultry feed. Supplementation of $50 \mu \mathrm{g}$ of vitamin $\mathrm{B}_{12}$ or of corresponding amount of fish meal, and of $0.1 \%$ of DL-methionine to the diet containing $15 \%$ of the yeast was satisfactory. With the supplemontation, hydrocarbon yeast is an excellent protein source for broiler.

(Japan. Poultry Sci., 10, 93 103, 1973) 